\title{
Vertical characterization of highly oxygenated molecules (HOMs) below and above a boreal forest canopy
}

\author{
Qiaozhi Zha ${ }^{1}$, Chao Yan ${ }^{1}$, Heikki Junninen ${ }^{1}$, Matthieu Riva ${ }^{1}$, Nina Sarnela ${ }^{1}$, Juho Aalto ${ }^{1}$, Lauriane Quéléver ${ }^{1}$, \\ Simon Schallhart ${ }^{1}$, Lubna Dada $^{1}$, Liine Heikkinen ${ }^{1}$, Otso Peräkylä ${ }^{1}$, Jun Zou ${ }^{2}$, Clémence Rose ${ }^{1}$, Yonghong Wang ${ }^{1}$, \\ Ivan Mammarella ${ }^{3}$, Gabriel Katul ${ }^{4,5}$, Timo Vesala ${ }^{1}$, Douglas R. Worsnop ${ }^{1,6}$, Markku Kulmala ${ }^{1}$, Tuukka Petäjä ${ }^{1}$, \\ Federico Bianchi ${ }^{1}$, and Mikael Ehn ${ }^{1}$ \\ ${ }^{1}$ Institute for Atmospheric and Earth System Research/Physics, Faculty of Science, University of Helsinki, \\ P.O. Box 64, 00014 Helsinki, Finland \\ ${ }^{2}$ CMA-NJU Joint Laboratory for Climate Prediction Studies, Institute for Climate and Global Change Research, \\ School of Atmospheric Sciences, Nanjing University, Nanjing, China \\ ${ }^{3}$ Institute for Atmospheric and Earth System Research/Physics, Faculty of Science, University of Helsinki, \\ P.O. Box 68, 00014 Helsinki, Finland \\ ${ }^{4}$ Nicholas School of the Environment, Duke University, Durham, North Carolina, USA \\ ${ }^{5}$ Department of Civil and Environmental Engineering, Duke University, Durham, North Carolina, USA \\ ${ }^{6}$ Aerodyne Research, Inc., Billerica, MA 01821, USA
}

Correspondence: Qiaozhi Zha (qiaozhi.zha@ @elsinki.fi) and Chao Yan (chao.yan@helsinki.fi)

Received: 24 November 2017 - Discussion started: 8 December 2017

Revised: 28 August 2018 - Accepted: 30 October 2018 - Published: 10 December 2018

\begin{abstract}
While the role of highly oxygenated molecules (HOMs) in new particle formation (NPF) and secondary organic aerosol (SOA) formation is not in dispute, the interplay between HOM chemistry and atmospheric conditions continues to draw significant research attention. During the Influence of Biosphere-Atmosphere Interactions on the Reactive Nitrogen budget (IBAIRN) campaign in September 2016, profile measurements of neutral HOMs below and above the forest canopy were performed for the first time at the boreal forest SMEAR II station. The HOM concentrations and composition distributions below and above the canopy were similar during daytime, supporting a well-mixed boundary layer approximation. However, much lower nighttime HOM concentrations were frequently observed at ground level, which was likely due to the formation of a shallow decoupled layer below the canopy. Near the ground HOMs were influenced by the changes in the precursors and oxidants and enhancement of the loss on surfaces in this layer, while the HOMs above the canopy top were not significantly affected. Our findings clearly illustrate that near-ground HOM measurements conducted under stably stratified conditions at this site might only be representative of a small fraction of the en-
\end{abstract}

tire nocturnal boundary layer. This could, in turn, influence the growth of newly formed particles and SOA formation below the canopy where the large majority of measurements are typically conducted.

\section{Introduction}

Highly oxygenated molecules (HOMs), a subgroup of the oxidation products of volatile organic compounds (VOCs) identified by their high oxidation states, have been recognized as important precursors for organic aerosol in the atmosphere (Ehn et al., 2014). They have also been found to enhance new particle formation (NPF) and growth (Kulmala et al., 2013; Zhao et al., 2013; Ehn et al., 2014; Bianchi et al., 2016; Kirkby et al., 2016; Tröstl et al., 2016). The importance of HOMs has been confirmed in ambient environments, especially in monoterpene-dominated regions such as the boreal forest (Kulmala et al., 2013; Ehn et al., 2014), but also in high-altitude mountain regions (Bianchi et al., 2016) and in rural areas (Jokinen et al., 2014; Kürten et al., 2016). In laboratory studies, HOM formation has been observed from var- 
ious precursor molecules (Ehn et al., 2017), including both biogenic and anthropogenic emissions (Molteni et al., 2018).

The direct observation of HOMs has only recently become possible, following the developments of the atmosphericpressure-interface time-of-flight (APi-TOF, measures the naturally charged HOMs) (Junninen et al., 2010) and chemical-ionization atmospheric-pressure-interface time-offlight (CI-APi-TOF, measures the neutral HOMs) (Jokinen et al., 2012) mass spectrometers. Ehn et al. (2010) and Bianchi et al. (2017) found that the naturally charged HOM clusters could be observed every night in the boreal forest during spring. Out of the observed ambient mass spectra, a significant part could be reproduced in a chamber by introducing the monoterpene $\alpha$-pinene $\left(\mathrm{C}_{10} \mathrm{H}_{16}\right.$, the major biogenic VOC in the boreal forest) and ozone $\left(\mathrm{O}_{3}\right)$ (Ehn et al., 2012).

Further investigations of HOM formation chemistry have been carried out in both laboratory and field studies. Based on current understanding from laboratory experiments, the formation of HOMs involves three main steps: (1) initial formation of peroxy radicals $\left(\mathrm{RO}_{2}\right)$ from VOC oxidation; (2) $\mathrm{RO}_{2}$ autoxidation, that is, the isomerization of the $\mathrm{RO}_{2}$ via intramolecular $\mathrm{H}$ shifts and subsequent oxygen $\left(\mathrm{O}_{2}\right)$ additions; and (3) radical termination, forming closed-shell molecules (Crounse et al., 2013; Ehn et al., 2014; Jokinen et al., 2014, 2016; Rissanen et al., 2014; Mentel et al., 2015). In the atmosphere, HOM formation studies are complicated by the plethora of different compounds and processes taking place. However, recent ambient measurements together with factor analysis were able to shed light on the HOM formation pathways in the boreal forest (Yan et al., 2016). They showed that the majority of the daytime production of HOMs was from reactions initiated by the oxidation of monoterpenes (MTs) with hydroxyl radicals $(\mathrm{OH})$ or $\mathrm{O}_{3}$. The $\mathrm{RO}_{2}$ after autoxidation were often terminated by hydroperoxyl radicals $\left(\mathrm{HO}_{2}\right)$ or self-termination (Orlando and Tyndall, 2012) to form a non-nitrate HOM monomer $\left(\mathrm{CHO}_{\text {monomer }}\right.$, mainly $\mathrm{C}_{9}$ and $\mathrm{C}_{10}$ compounds, with masses between 290 and $450 \mathrm{Th}$ after clustering with the charging ion $\left(\mathrm{NO}_{3}^{-}\right)$of the instrument), or reacting with nitrogen oxides $\left(\mathrm{NO}_{x}=\mathrm{NO}+\mathrm{NO}_{2}\right)$ to form organonitrate $\mathrm{HOM}$ monomers $\left(\mathrm{CHON}_{\text {monomer }}\right)$. During nighttime, MTs were mainly oxidized by $\mathrm{O}_{3}$ and $\mathrm{NO}_{3}$ radicals. Furthermore, due to the lower nocturnal $\mathrm{HO}_{2}$ and $\mathrm{NO}_{x}$ concentrations, in addition to the production of $\mathrm{CHON}_{\text {monomer }}$, the $\mathrm{RO}_{2}$ products readily reacted with other $\mathrm{RO}_{2}$ to form either non-nitrate HOM dimers $\left(\mathrm{CHO}_{\text {dimer }}\right.$, mainly $\mathrm{C}_{16-20}$ compounds with masses between 450 and $600 \mathrm{Th}$ after clustering with $\mathrm{NO}_{3}^{-}$) or organonitrate $\mathrm{HOM}$ dimers $\left(\mathrm{CHON}_{\text {dimer }}\right)$, depending on the oxidants forming the $\mathrm{RO}_{2}$ (Ehn et al., 2014; Jokinen et al., 2014; Yan et al., 2016; Berndt et al., 2018).

Beyond those chemical pathways, varied meteorological conditions are also factors influencing the MT and oxidants at different heights above the forest floor. Unsurprisingly, the oxidants producing HOMs (e.g., $\mathrm{O}_{3}$ ) have been found almost uniformly distributed within the well-mixed daytime boundary layer (Chen et al., 2018). In contrast, the nocturnal boundary layer was shallow with stability regimes that depended on radiative cooling within the canopy and turbulent shear stresses at the canopy top. In Hyytiälä, the depletion of $\mathrm{O}_{3}$ below the canopy has been frequently observed during nighttime, while the $\mathrm{O}_{3}$ above the canopy was less affected (Chen et al., 2018). The MT concentration at ground level increased when $\mathrm{O}_{3}$ was depleted (Eerdekens et al., 2009). The inhomogeneous distribution of the precursors and oxidants below and above the canopy might further impact nocturnal HOM distributions, which frames the scope of this study. Until now, all CI-APi-TOF deployments have been at ground level, and the main subject of inquiry here is the vertical information on HOMs and the role of meteorological condition in shaping them. A characterization of the HOMs at different heights provides a decisive advantage in disentangling the role of nonuniform mixing within the atmospheric layers impacted by strong thermal stratification, especially inside the canopy volume.

The first measurements of the HOM concentrations at two different heights ( $36 \mathrm{~m}$ and $1.5 \mathrm{~m}$ a.g.l.) are presented and discussed. The influence of boundary layer dynamics on the HOMs at these different heights at SMEAR II station is analyzed and characterized in conjunction with auxiliary turbulence and micrometeorological measurements.

\section{Experimental}

\subsection{Measurement site description}

The measurements were performed at the SMEAR II station (Station for Measuring Ecosystem-Atmosphere Relations) in the boreal forest in Hyytiälä, southern Finland $\left(61^{\circ} 51^{\prime} \mathrm{N}\right.$, $24^{\circ} 17^{\prime}$ E, $181 \mathrm{~m}$ a.s.l.; Hari and Kulmala, 2005; Hari et al., 2013) during September 2016. There is no large anthropogenic emission source at or near the site. The closest sources are the two sawmills $\sim 5 \mathrm{~km}$ southeast of the site and the city area of Tampere ( $\sim 60 \mathrm{~km}$ away). The forest surrounding the station is primarily Scots pine with a mean canopy height of $\sim 17.5 \mathrm{~m}$, a total leaf area index (LAI) of $\sim$ $6.5 \mathrm{~m}^{2} \mathrm{~m}^{-2}$, a stand density of $\sim 1400$ trees ha ${ }^{-1}$, and an average diameter at breast height (DBH) of $\sim 0.16 \mathrm{~m}$ (Bäck et al., 2012; Launiainen et al., 2013). The forest floor is majorly covered with a shallow dwarf shrub (a LAI of $\sim 0.5 \mathrm{~m}^{2} \mathrm{~m}^{-2}$ ) and moss layer (a LAI of $\sim 1 \mathrm{~m}^{2} \mathrm{~m}^{-2}$ ) (Kulmala et al., 2008; Launiainen et al., 2013). The planetary boundary layer height at the SMEAR II station has been determined from previous studies using radiosondes (Lauros et al., 2007; Ouwersloot et al., 2012) and balloon soundings (Eerdekens et al., 2009). Roughly, these heights span some $400 \mathrm{~m}$ (March) to $1700 \mathrm{~m}$ (August) at noontime and $100 \mathrm{~m}$ (March) to $<160 \mathrm{~m}$ (April) at midnight. 


\subsection{Instrumentation}

Concentration of HOMs was measured with two nitrate-ionbased CI-APi-TOF mass spectrometers. The CI-APi-TOF measuring at higher altitude was deployed at the top of a $35 \mathrm{~m}$ tower located $\sim 20 \mathrm{~m}$ horizontally from the ground measurement location. Both instruments were working in rooms with air-conditioning and room temperatures controlled at $25^{\circ} \mathrm{C}$. The inlets of the two instruments were pointed to the southeast direction and fixed at $\sim 36$ and $\sim 1.5 \mathrm{~m}$ above ground. The tower measurement is at about twice the canopy height, which is still within the roughness sublayer of the forest (Raupach and Thom, 1981). The instrument setup of the two CI-APi-TOF mass spectrometers was similar. In brief, the CI-APi-TOF was the combination of a chemical ionization (CI) inlet and an APi-TOF mass spectrometer (Aerodyne Research Inc., USA, and Tofwerk AG, Switzerland). The ambient air was first drawn into the inlet with a sample flow of $7 \mathrm{~L} \mathrm{~min}^{-1}$ (liter per minute) and then centered to an ion reaction tube surrounded by sheath flow (filtered air, $35 \mathrm{~L} \mathrm{~min}^{-1}$ ). Meanwhile, the nitrate ions carried by the sheath gas, which were generated by exposing the nitric acid $\left(\mathrm{HNO}_{3}\right)$ to soft $\mathrm{X}$-ray radiation, were guided into the sample gas by an electrical field at ambient pressure $(\sim 100 \mathrm{~ms}$ reaction time). Neutral molecules $(M)$ in the sample air were ionized by either clustering with charged nitrate / nitric acid $\left(\left(\mathrm{HNO}_{3}\right)_{n=0-2} \cdot \mathrm{NO}_{3}^{-}\right)$to form $(M) \cdot \mathrm{NO}_{3}^{-}$cluster ions or losing a proton to the charging ions to form deprotonated ions (e.g., $\mathrm{H}_{2} \mathrm{SO}_{4}+\mathrm{NO}_{3}^{-} \rightarrow \mathrm{HSO}_{4}^{-}+\mathrm{HNO}_{3}$ ). The ions then entered the APi part, which was a three-stage vacuum chamber, through a pinhole. In the APi, two quadrupoles and a stack of ion lenses guided the ions into the TOF mass analyzer, in which ions were separated based on their mass-tocharge $(m / z)$ ratios. A more detailed description of this instrument has been given by Junninen et al. (2010) and Jokinen et al. (2012), and discussion on selectivity of this nitrate ion charging was provided by Hyttinen et al. (2015). Mass spectra obtained from the instrument were analyzed using the "tofTools" program described in Junninen et al. (2010). Determination of the concentration of a measured molecule $M$ was based on the following equation:

$[M]=\frac{\sum M}{\sum \text { reagent ion count rates }} \times C$,

where the sum of ion count rates $\left(\sum M\right)$ in the numerator includes all detected ions relating to compound $M$, whether deprotonated or in clusters with reagent ions, and the sum of reagent ion count rates in the denominator is the total signal of the nitrate ions. $C$ is the calibration coefficient, which was assigned the same value for all detected compounds. This assignment is only valid for compounds that cluster with the reagent ions at the collision limit, such as $\mathrm{H}_{2} \mathrm{SO}_{4}$ (Viggiano et al., 1997), and have equal collision rates. The collision rates of nitrate ions with $\mathrm{H}_{2} \mathrm{SO}_{4}$ and with $\mathrm{HOMs}$ are expected to be very close (Ehn et al., 2014). Here, a cali- bration coefficient of $1 \times 10^{10}$ molec $\mathrm{cm}^{-3}$, estimated from previous calibrations with similar settings using sulfuric acid and theoretical constraints (Ehn et al., 2014), with an uncertainty of at least $-50 \% /+100 \%$, was used in calculating the HOM concentrations for both instruments. Ultimately, the absolute HOM concentrations in this work are of secondary importance, as we focus on the relative comparison of HOM concentrations measured at different heights. However, the comparability of the two CI-APi-TOF instruments is of great importance, and results cannot be allowed to vary as a result of inevitable differences in the mass-dependent transmission efficiency (TE), for example. For a detailed discussion on factors affecting the TE of a CI-APi-TOF, we refer to Heinritzi et al. (2016). To this end, instead of directly evaluating the TE of each instrument, a "relative" TE of the two CI-APi-TOFs was used for data correction: we selected a time period at noontime on 9 September with a well-mixed boundary layer, identified by the clear and sunny weather and homogeneous vertical distribution of monoterpene and other trace gases, and we assumed the HOM concentrations at the two heights to be the same. Thus, the relative TE was obtained from the concentration ratio between the two CIAPi-TOFs at each $m / z$ (Fig. 1). A fitted relative TE curve $\left(R^{2}=0.97\right)$, which represents how the TE of the tower CIAPi-TOF was changed at each $m / z$ over the TE of the ground one, was obtained using power-law regression. Weaker correlation was obtained in the 200-250 and 500-600 Th mass ranges, but in the mass range in which most of the HOMs were located $(290-500 \mathrm{Th})$ there is very little scatter around the fitted curve, clearly suggesting that observed differences in the two instruments' responses were mainly due to differences in TE. To test our assumption of negligible vertical gradients of HOMs during daytime, we analyzed the behavior of sulfuric acid. We found that the uncertainty related to this assumption corresponds to a value of $26 \%$ (see Fig. S1 in the Supplement). An upper limit of uncertainty relating to our TE correction (Fig. 1) was also estimated, yielding a value of $10 \%$, giving a total uncertainty from these two sources of $28 \%$. This value is much smaller than the observed deviation of HOM concentrations during inversion nights, as will be discussed later. Additionally, an intercomparison between the two instruments with a permeation tube containing trinitrotriazinane $\left(\mathrm{C}_{3} \mathrm{H}_{6} \mathrm{~N}_{6} \mathrm{O}_{6}\right)$ was conducted in the field right after the campaign. The results showed good agreement with the relative TE, lending confidence to the method used here. Finally, it should be noted that the difference in TE between the two instruments was larger than one would normally expect since the tower CI-APi-TOF had been tuned for higher sensitivity at the largest masses (at the expense of transmission at the lower masses).

In comparison to the direct determination of TE (Heinritzi et al., 2016), this method increases the uncertainty in the quantification of HOM concentrations. However, as mentioned, a more accurate knowledge of the exact HOM con- 


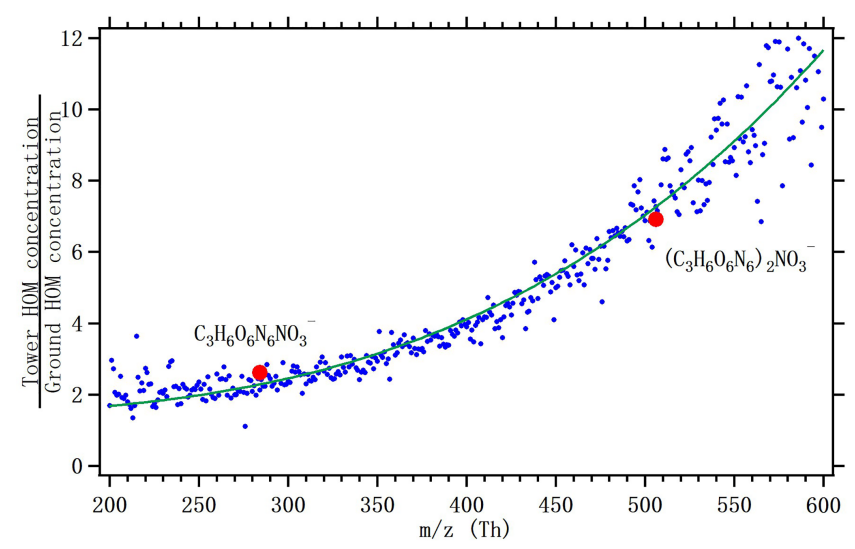

Figure 1. The relative transmission curve between the two CI-APiTOF mass spectrometers, determined during a period of strong turbulent mixing. Intercomparison results using a permeation tube containing trinitrotriazinane $\left(\mathrm{C}_{3} \mathrm{H}_{6} \mathrm{~N}_{6} \mathrm{O}_{6}\right)$ are shown in red circles. The fitted green line was used to scale the measured signals between the two instruments to match, in order to compare relative changes during times of limited vertical mixing.

centrations would not influence the main findings of this study.

The MT, trace gases, and meteorological parameters were continuously monitored at the different heights $(4.2,8.4$, $16.8,33.6,50.4,67.2,101$, and $125 \mathrm{~m}$ ) on a $126 \mathrm{~m}$ mast $\sim 100 \mathrm{~m}$ away from the location of the CI-APi-TOFs. The data at 4.2 and $33.6 \mathrm{~m}$ were used in this study to represent the concentrations at near ground and tower levels, respectively. MT concentrations were measured every third hour using a proton transfer reaction mass spectrometer with a lower detection limit of 1 pptv (PTR-MS, Ionicon Analytik GmbH; Taipale et al., 2008). The $\mathrm{O}_{3}$ concentration was measured with a UV light absorption analyzer that had a lower detection limit of $1 \mathrm{ppbv}$ (TEI model 49C, Thermo Fisher Scientific, USA). The $\mathrm{NO}_{x}$ measurement was conducted using a chemiluminescence analyzer (TEI model 42C TL, Thermo Fisher Scientific, USA). The lower detection limit of the $\mathrm{NO}_{x}$ analyzer is 100 pptv. The $\mathrm{CO}_{2}$ measurement was performed using an infrared detection system (LI-840, LI-COR Biosciences, Lincoln, NE, USA). The aerosol number concentration size distributions were obtained with a twin differential mobility particle sizer (twin DMPS) for the size range from 3 to $1000 \mathrm{~nm}$ (Aalto et al., 2001) at $8 \mathrm{~m}$ in height above ground, and was used to calculate condensation sink (CS) based on the method from Kulmala et al. (2001). Air temperature was measured with PT-100 resistance thermometers. Air relative humidity (RH) was measured with RH sensors (Rotronic HygroMet model MP102H with HygroClip HC2S3, Rotronic AG, Switzerland). Global radiation (solar radiation in the wavelength range of $0.3-4.8 \mu \mathrm{m}$ ) was obtained with a Pyranometer (Reemann TP3, Astrodata, Estonia) above the canopy top at $18 \mathrm{~m}$. All the data presented are at 10 min averaging intervals, except for the MT (at a $1 \mathrm{~h}$ averaging interval). A schematic figure showing sampling locations of all the measured parameters is provided in Fig. S2.

\section{Results and discussion}

\subsection{Data overview}

The Influence of Biosphere-Atmosphere Interactions on the Reactive Nitrogen budget (IBAIRN) campaign was conducted from 1 to 25 September 2016. After data quality checks, only the measurements collected after 5 September were used. Figure 2 shows the overall time series of the meteorological parameters measured at ground and tower levels, including the temperature, $\mathrm{RH}$, global radiation, concentrations of trace gases, MT, and total HOMs (Zha, 2018). The weather was generally sunny and clear during the campaign except for a few cloudy $(10,15$, and 22-23 September) and drizzling (24 and 25 September) days. The mean air temperature and RH observed at ground level were $10.8 \pm 3.3{ }^{\circ} \mathrm{C}$ and $87 \pm 13 \%$ ( $1 \sigma$ standard deviation) and at the tower level were $10.5 \pm 3.0^{\circ} \mathrm{C}$ and $88 \pm 14 \%$, respectively. The $\mathrm{O}_{3}$ concentrations measured at ground and tower levels were $21 \pm 8$ and $25 \pm 6$ ppbv, respectively. The air temperature, $\mathrm{RH}$, and $\mathrm{O}_{3}$ measured at the two heights were close to each other during daytime. The $\mathrm{NO}_{x}$ concentrations were quite low throughout the campaign; the mean $\mathrm{NO}_{x}$ concentrations were mostly around the reported detection limit at $0.4 \pm 0.4 \mathrm{ppbv}$ (ground) and $0.4 \pm 0.5 \mathrm{ppbv}$ (tower), yet showed an overall good agreement between the measurements at the different heights. The MT concentrations at ground level $(0.38 \pm 0.34$ ppbv on average) were generally higher than those above the canopy level $(0.20 \pm 0.16 \mathrm{ppbv})$.

The estimated total HOM concentration is representative for the overall concentration level of HOMs and is here defined as the sum of the detected signals among ions from $\mathrm{m} / \mathrm{z}, 200$ to 600 after removing identified background peaks. The gaps in the estimated total HOM at ground level were due to automatic zero checks. During the campaign, a significant difference was found in the estimated total HOM concentrations below and above the canopy (mean and median concentrations of $1.1 \pm 1.7 \times 10^{8}$ and $0.8 \times 10^{8} \mathrm{~cm}^{-3}$ at ground level and $1.7 \pm 1.3 \times 10^{8}$ and $1.3 \times 10^{8} \mathrm{~cm}^{-3}$ at tower level). The causes of these differences $(\sim 55 \%$ in mean and $\sim 71 \%$ in median) frame the upcoming discussion.

\subsection{Intercomparison of estimated total HOM concentrations}

The estimated total HOM concentrations at the two heights were not different during the day (mean $\pm 1 \sigma$ standard deviation and median concentrations of $4.1 \pm 2.3 \times 10^{8}$ and $3.6 \times 10^{8} \mathrm{~cm}^{-3}$ at ground level, $4.3 \pm 2.6 \times 10^{8}$ and $4.0 \times$ $10^{8} \mathrm{~cm}^{-3}$ at tower level), which validates the use of only 1 day of data for scaling the TE of the ground CI-APi-TOF to 


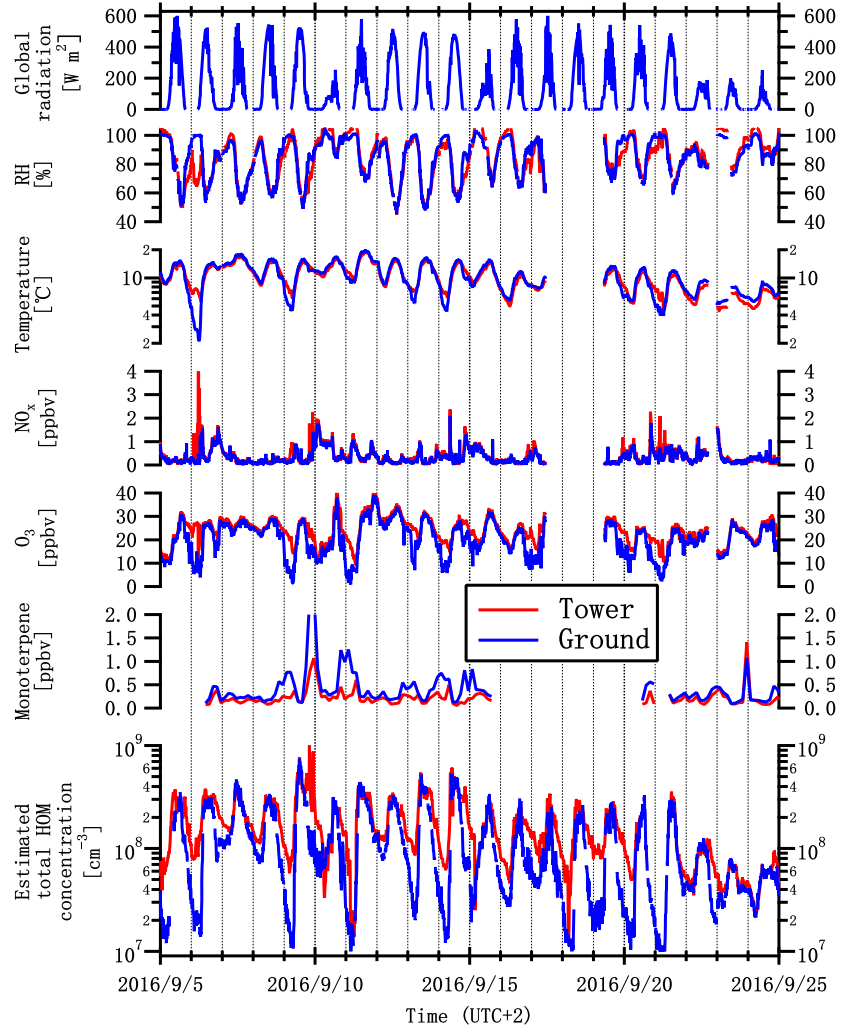

Figure 2. The overall time series of the measured trace gases, meteorological parameters, and estimated total HOM concentrations at the ground (blue) and tower (red) levels.

match the HOM signals of the two instruments. The good daytime agreement throughout the campaign period also verifies that the response of each instrument stayed stable. Contrary to the daytime results, the estimated total HOM concentration at ground level usually diverged from the tower measurement in the nocturnal boundary layer. The concentration below the canopy became even lower when temperature inversions were observed, accompanied by a decreasing ground-level $\mathrm{O}_{3}$ and increasing MT concentrations. Figure 3 shows a comparison between the estimated total HOM concentrations observed at two heights. Herein, good agreement could be found for the group of points representing the concentrations around noontime $\left(R^{2}=0.89\right)$. The points indicating the nighttime estimated total HOM concentrations were scattered $\left(R^{2}=0.28\right)$, and the ground concentrations were found to be much lower than the tower ones.

Figure 4 shows the mean mass spectra (in unit mass resolution, UMR, for $m / z$ 200-600) obtained from the ground and tower. It is worth mentioning that there might be some signals not attributable to HOMs in the plotted spectra, but only as a small proportion. Only selected periods (09:00-15:00 for daytime and 21:00-03:00 for nighttime; all the times are given in Finnish winter time, UTC +2) are included in the averaging period to eliminate the effect of sunrise and sun-

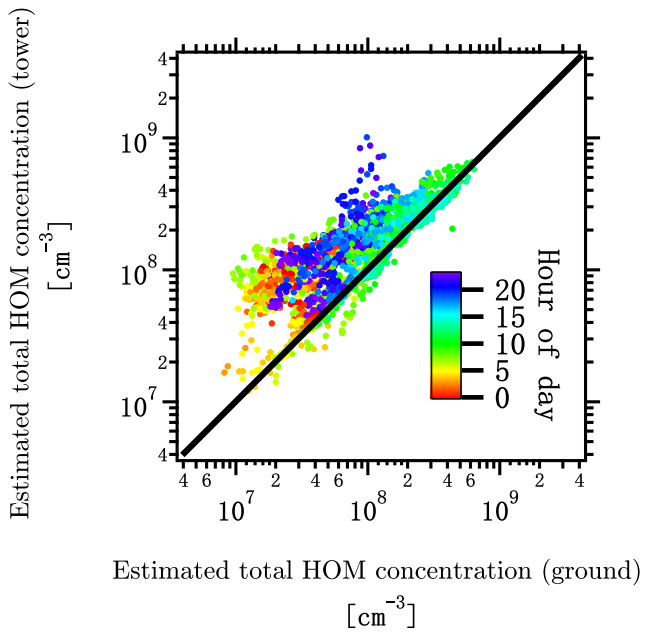

Figure 3. Comparison between ground ( $x$ axis) and tower ( $y$ axis) measurements of the estimated total HOM concentrations. The black line denotes the $1: 1$ ratio. Color code indicates the sampling time of HOMs

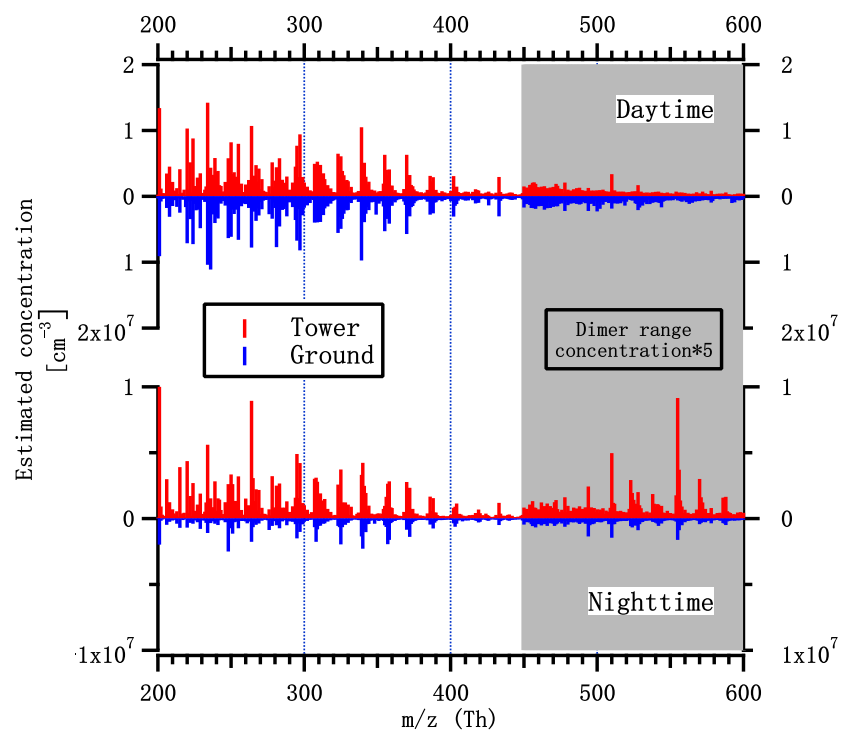

Figure 4. Mean mass spectra with the averaging periods of daytime (09:00-15:00) and nighttime (21:00-03:00) at the ground and tower levels.

set periods. During daytime, a good agreement $\left(R^{2}=0.87\right)$ was obtained from the mass-by-mass comparison using the UMR concentrations extracted from daytime mean spectra, suggesting a uniform composition distribution in the daytime boundary layer condition. During nighttime, the mean concentrations of all HOMs in the ground mean spectra were much lower than the tower spectra. The HOM concentrations shown in the ground and tower mean spectra were also less correlated. Therefore, a logical outcome is that the conditions below and above the canopy experience different turbu- 
lent mixing strength and/or source-sink regimes during the night.

\subsection{Influence of nocturnal boundary layer dynamics and micrometeorological processes}

The nighttime HOMs at ground level are likely influenced by transport processes below the canopy since the estimated total HOM concentrations were found much lower on the nights when temperature inversions were observed. To further investigate the potential impact of such micrometeorological phenomena on ground-level HOMs, the nights during the campaign without precipitation or instrument failure were selected (14 nights in total) and categorized into two types based on the occurrence of temperature inversions: (1) the "non-inversion night" type included seven nights when no temperature inversion was recorded; (2) the "inversion night" type category consisted of seven nights that had encountered temperature inversions, and the ground temperatures were generally $\sim 1{ }^{\circ} \mathrm{C}$ lower than tower temperatures during these nights.

\subsubsection{Statistics of the non-inversion night and inversion night types}

Table 1 shows the overall statistics including the mean and median values of the temperatures, $\mathrm{O}_{3}, \mathrm{NO}_{x}$, MT, and estimated total HOM concentrations for the non-inversion night and inversion night types. On the non-inversion nights, the air below and above the canopy was relatively well mixed. The mean and median concentrations of the ground $\mathrm{O}_{3}(21 \pm 8$ and $22 \mathrm{ppbv})$ were close to the tower values $(25 \pm 6$ and 24 ppbv). The slight difference might be attributed to the higher VOC emissions (Rantala et al., 2014) and larger sink near ground level. In contrast, during the inversion nights, the mean estimated total $\mathrm{HOM}$ concentration and $\mathrm{O}_{3}$ at ground level were generally much lower, only $\sim 33 \%$ and $\sim 69 \%$ of the tower concentrations, respectively. Instead, the mean and median ground MT concentration $(0.70 \pm 0.28$ and $0.70 \mathrm{ppbv}$ ) were $\sim 3$ times higher than the tower ones $(0.24 \pm 0.04$ and $0.23 \mathrm{ppbv})$. The measured $\mathrm{NO}_{x}$ levels were similar in both categories and at both heights, though the ambient concentrations were close to the detection limit and therefore small differences might not be observable.

\subsubsection{Case study}

Two individual nights representing the non-inversion night and inversion night types were selected and further compared. Figure 5a shows the time series of the meteorological parameters, trace gases, and HOMs measured at ground and tower levels of one selected night for the non-inversion night type (11-12 September, from 21:00 to 03:00). A number of measures can be used to assess the local atmospheric stability conditions at a given layer. These measures are commonly based on either the Obukhov length and its associated at- mospheric stability parameter or a Richardson number (flux based, gradient based, or bulk). Because of its simplicity and the availability of high-resolution mean air temperature profiles, the bulk Richardson number $(R i)$ was used here (Mahrt et al., 2001; Mammarella et al., 2007; Vickers et al., 2012; Alekseychik et al., 2013). It is calculated using

$R i=\frac{g \Delta \bar{\theta} \Delta z}{\bar{\theta}(\bar{u})^{2}}$,

where $g$ is the gravitational acceleration, $\Delta \bar{\theta}$ and $\Delta z$ are the mean potential temperature $(10 \mathrm{~min}$ averaging interval, same as measurement data) and height difference between the ground and tower levels, respectively, and $\bar{\theta}$ and $\bar{u}$ are the mean potential temperature and mean wind velocity at tower level, respectively. During the selected non-inversion night, $R i$ was generally positive but close to 0 (shown in Fig. 5a), indicating a weakly stable and relatively well-mixed (i.e., $\Delta \bar{\theta} \rightarrow 0$ ) condition (Mahrt, 1998; Mammarella et al., 2007). This was also confirmed using the well-correlated ground and tower MT and trace gas concentrations.

Selected HOMs representing the major HOM types (and formation pathways) were summed up and categorized into four groups, as shown in Table 2. Each pathway might be influenced differently by boundary layer dynamics and micrometeorological processes. In this study, $\mathrm{OH}$-initiated HOMs were assumed negligible due to the very low $\mathrm{OH}$ level in the nocturnal boundary layer.

All the HOM groups in Fig. 5a show stable patterns, and good agreement is observed between the ground and tower measurements in the first half of the night. Variations were observed when air mass change occurred at around 01:00, as indicated by the drop of $\mathrm{NO}_{x}$ concentration and horizontal wind shift (not shown here). A rapid decrease was found in CS, which represents the rate of condensation of lowvolatility vapors onto the existing aerosol particles (Dada et al., 2017), implying that the aerosol population also changed. However, the HOM groups were still well correlated with each other, suggesting well-mixed conditions in the noninversion night.

Figure $5 \mathrm{~b}$ shows the time series of the trace gases, MT, and HOM groups of both ground and tower measurements during an inversion night case (8-9 September, from 21:00 to $03: 00)$. $R i$ was generally higher during this night, and increased from $\sim 0.03$ (indicating a weakly stable condition; Mammarella et al., 2007), at around midnight, to a maximum of $\sim 1.13$ (indicating a very stable condition) for the rest of the night. Roughly, $R i$ values in excess of unity indicate that stably stratified conditions appreciably diminish the inverse turbulent Prandtl number $(P r)$ and the efficiency of turbulence to mix heat when compared to momentum (Katul et al., 2014). The parameters measured at tower level were not significantly affected by strong $R i$ fluctuations throughout the night; in contrast, significant variations were observed at ground level. 
Table 1. Summary of the "Non-inversion night" and "Inversion night" types.

\begin{tabular}{|c|c|c|c|c|c|c|c|c|c|c|c|}
\hline \multicolumn{2}{|l|}{ Type } & \multicolumn{5}{|c|}{ Non-inversion night } & \multicolumn{5}{|c|}{ Inversion night } \\
\hline \multicolumn{2}{|l|}{ Date } & \multicolumn{5}{|c|}{$6,7,9,11,15,16,21$ September $^{\mathrm{a}}$} & \multicolumn{5}{|c|}{$5,8,10,12,13,14,19$ September $^{\mathrm{b}}$} \\
\hline Paramete & & $\begin{array}{r}\text { Temperature } \\
\left({ }^{\circ} \mathrm{C}\right)\end{array}$ & $\begin{array}{r}\mathrm{O}_{3} \\
\text { (ppbv) }\end{array}$ & $\begin{array}{r}\mathrm{NO}_{x} \\
\text { (ppbv) }\end{array}$ & $\begin{array}{r}\text { MT } \\
\text { (ppbv) }\end{array}$ & $\begin{array}{r}\text { Estimated } \\
\text { total HOM } \\
\left(10^{8} \mathrm{~cm}^{-3}\right)\end{array}$ & $\begin{array}{r}\text { Temperature } \\
\left({ }^{\circ} \mathrm{C}\right)\end{array}$ & $\begin{array}{r}\mathrm{O}_{3} \\
\text { (ppbv) }\end{array}$ & $\begin{array}{r}\mathrm{NO}_{x} \\
(\mathrm{ppbv})\end{array}$ & $\begin{array}{r}\text { MT } \\
\text { (ppbv) }\end{array}$ & $\begin{array}{r}\text { Estimated } \\
\text { total HOM } \\
\left(10^{8} \mathrm{~cm}^{-3}\right)\end{array}$ \\
\hline Tower & $\begin{array}{l}\text { Mean } \pm 1 \sigma \text { standard } \\
\text { deviation }\end{array}$ & $10.2 \pm 2.6$ & $25 \pm 6$ & $0.5 \pm 0.5$ & $0.31 \pm 0.31$ & $2.9 \pm 1.9$ & $9.5 \pm 1.7$ & $24 \pm 2$ & $0.4 \pm 0.3$ & $0.24 \pm 0.04$ & $2.4 \pm 0.8$ \\
\hline Ground & Median & 11.5 & 22 & 0.3 & 0.22 & 1.7 & 8.5 & 17 & 0.3 & 0.70 & 0.7 \\
\hline
\end{tabular}

${ }^{\text {a }}$ MT data not available on 5 and 19 September. ${ }^{\text {b }}$ MT data not available on 15 and 16 September.

Table 2. Compositions of selected HOMs and their main oxidants (Yan et al., 2016).

\begin{tabular}{llll}
\hline & Molecule compositions & Main oxidants & Main terminators \\
\hline $\mathrm{CHO}_{\text {monomer }}$ & $\mathrm{C}_{10} \mathrm{H}_{14} \mathrm{O}_{7}, \mathrm{C}_{10} \mathrm{H}_{14} \mathrm{O}_{9}$ & $\mathrm{O}_{3}$ & Self-termination or $\mathrm{RO}_{2}$ \\
$\mathrm{CHON}_{\text {monomer }}$ & $\mathrm{C}_{10} \mathrm{H}_{15} \mathrm{O}_{9} \mathrm{~N}, \mathrm{C}_{10} \mathrm{H}_{15} \mathrm{O}_{11} \mathrm{~N}$ & $\mathrm{O}_{3}$ or $\mathrm{NO}_{3}$ & NO or self-termination- $\mathrm{RO}_{2}$ \\
$\mathrm{CHO}_{\text {dimer }}$ & $\mathrm{C}_{19} \mathrm{H}_{28} \mathrm{O}_{11}, \mathrm{C}_{20} \mathrm{H}_{30} \mathrm{O}_{14}$ & $\mathrm{O}_{3}$ & $\mathrm{RO}_{2}$ \\
$\mathrm{CHON}_{\text {dimer }}$ & $\mathrm{C}_{20} \mathrm{H}_{32} \mathrm{O}_{12} \mathrm{~N}_{2}, \mathrm{C}_{20} \mathrm{H}_{31} \mathrm{O}_{13} \mathrm{~N}$ & $\mathrm{NO}_{3}$ & $\mathrm{RO}_{2}$ \\
\hline
\end{tabular}

The ground $\mathrm{O}_{3}$ concentration experienced a rapid decrease at midnight. In about an hour (from 23:30 to 00:30), ground $\mathrm{O}_{3}$ concentration dropped by more than half (from 20 to $9 \mathrm{ppbv}$ ), and $\mathrm{CO}_{2}$ concentration increased as well (from 404 to $423 \mathrm{ppbv}$ ). Conversely, the MT concentration at ground level almost doubled (from 0.49 to $0.80 \mathrm{ppbv}$ ) during the same period. Theoretically, the enhancement of HOM precursor VOC and the decrease in oxidant would compensate for each other if the sink remained the same, and the ground HOM concentrations should also remain constant. However, all the HOM groups showed a significant decrease after midnight, despite the CS (generally the main sink for HOM in the atmosphere) staying practically constant. In particular, the concentration of the $\mathrm{CHO}_{\text {monomer }}$ group dropped $\sim 80 \%$, from $8.6 \times 10^{6}$ to $1.7 \times 10^{6} \mathrm{~cm}^{-3}$, and the concentration of the $\mathrm{CHO}_{\text {dimer }}$ group decreased from $1.5 \times 10^{6}$ to $~$ $0.1 \times 10^{6} \mathrm{~cm}^{-3}$. The concentrations of the $\mathrm{CHON}_{\text {monomer }}$ and $\mathrm{CHON}_{\text {dimer }}$ groups also experienced large declines $(\sim 34 \%$ and $\sim 50 \%$, respectively) in the latter half of the night. At 03:00, the $\mathrm{CHON}_{\text {dimer }}$ concentration was already below the detection limit $\left(1 \times 10^{4} \mathrm{~cm}^{-3}\right)$. Therefore, the much lower ground HOM concentrations might not be totally explained by the change of HOM production but rather due to some other processes such as additional losses.

A previous study by Alekseychik et al. (2013) at the SMEAR II station showed that nocturnal decoupled air layers were frequently (with a fraction of $18.6 \%$ based on a long-term dataset) observed under high-Ri conditions in the boreal forest. The decoupled layer could strongly influence the ground $\mathrm{O}_{3}, \mathrm{MT}$, and $\mathrm{CO}_{2}$ concentrations (Rannik et al.,
2009, 2012; Alekseychik et al., 2013; Chen et al., 2018) and could also explain the occurrence of the strong temperature inversion during the inversion nights. To explore the possible mechanism resulting in significantly different $\mathrm{O}_{3}, \mathrm{MT}$, and HOM concentrations below the canopy, the mean continuity equation for high-Reynolds-number flows within the canopy is formulated as (e.g., Katul et al., 2006)

$$
\begin{aligned}
& \frac{\partial \bar{C}}{\partial t}+\bar{U} \frac{\partial \bar{C}}{\partial x}+\bar{W} \frac{\partial \bar{C}}{\partial z}=-S-\frac{\partial \overline{w^{\prime} c^{\prime}}}{\partial z}-\frac{\partial \overline{u^{\prime} c^{\prime}}}{\partial x}, \\
& N_{1}+N_{2}+N_{3}=N_{4}+N_{5}+N_{6},
\end{aligned}
$$

where $t$ is time, $x$ and $z$ are the longitudinal and vertical directions, respectively, $C$ is the scalar concentration, $U$ and $W$ are the longitudinal and vertical velocity components, $\overline{w^{\prime} c^{\prime}}$ and $\overline{u^{\prime} c^{\prime}}$ are the turbulent scalar fluxes in the vertical and horizontal, respectively, $S$ represents the net sources or sinks (physical, chemical, and biological) of $C$, and the overline represents time averaging over turbulent scales. The six terms in this equation represent the following (left to right): local rate of change $\left(N_{1}\right)$, horizontal advection by the mean velocity $\left(N_{2}\right)$, vertical advection by the mean velocity $\left(N_{3}\right)$, net sources or sinks $\left(N_{4}\right)$, net vertical transport by the vertical turbulent flux gradient $\left(N_{5}\right)$, and net horizontal transport by the horizontal turbulent flux gradient $\left(N_{6}\right)$. Generally, $\left|N_{6}\right| \ll\left|N_{5}\right|$ and is hereafter ignored in the discussion.

During the non-inversion night, the ground $\mathrm{O}_{3}$ could be replenished by vertical turbulent transport $\left(N_{5}\right)$, mean vertical advection from the upper boundary layer $\left(N_{3}\right)$, or horizontal advection below the canopy $\left(N_{2}\right)$ (as shown in Fig. 6). However, for highly stratified flows, $N_{5}$ becomes small, as 

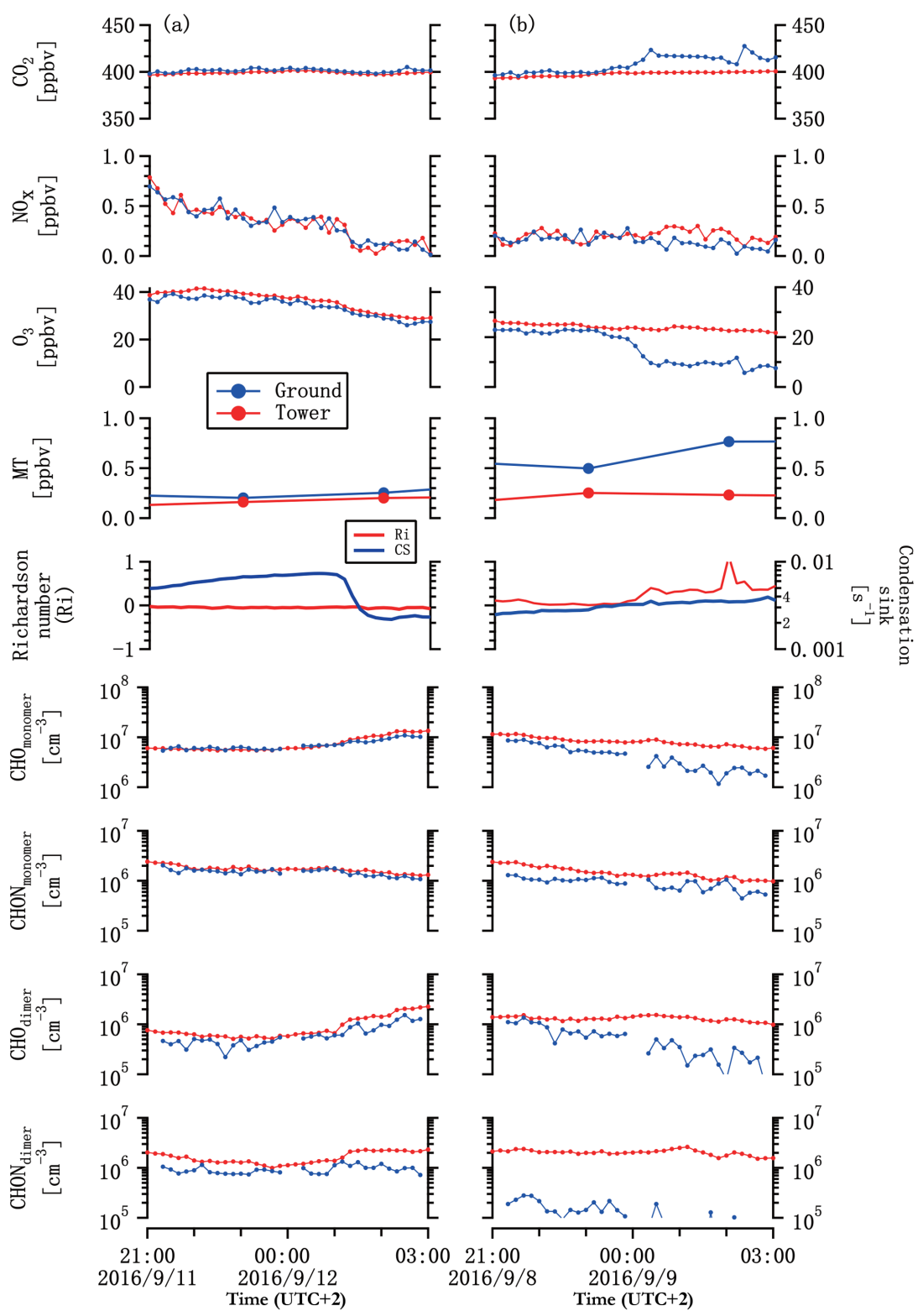

Figure 5. (a) Time series of ground and tower concentrations of $\mathrm{CO}_{2}, \mathrm{NO}_{x}, \mathrm{O}_{3}, \mathrm{MT}$, and selected HOM groups in the selected non-inversion night (11 September) and (b) inversion night (8 September) types. Ri is calculated with the meteorology data of the ground and tower levels. $\mathrm{CS}$ is determined based on the aerosol data measured at $8 \mathrm{~m}$ above ground level.

the efficiency of turbulence to transport $\mathrm{O}_{3}$ to layers near the ground becomes weak (Katul et al., 2014). Vertical and horizontal advection were also small within such a stable layer, and the reduced mean velocity would result in smaller contributions from $N_{2}$ and $N_{3}$. Note that these advective terms tend to be opposite in sign by the virtue of the mean fluid continuity equation (Katul et al., 2006). Instead, the sink of $\mathrm{O}_{3}\left(N_{4}\right)$ was stronger because of the increasing loss due to a higher surface area-to-volume density $(S / V)$ in this shallow decoupled layer. Under this circumstance, the ground $\mathrm{O}_{3}$ concentration dramatically decreased when the air layer was forming and eventually reached a much lower concentration. The decoupled layer also affected MT and $\mathrm{CO}_{2}$ below the canopy in the inversion night but resulted in concentration increases as opposed to $\mathrm{O}_{3}$. The weakened vertical turbulence $\left(N_{5}\right)$ tended to retain the emissions from ground and understory vegetation within the layer, though $N_{4}$ also increased. In general, the increased $\mathrm{CO}_{2}$ (primary source from the ground) and MT (primary source from the canopy) at ground level are good indicators for the extent of the mixing in the shallow decoupled layer. At the same time, the strong decrease in $\mathrm{O}_{3}$ shows how the sinks in this layer are 

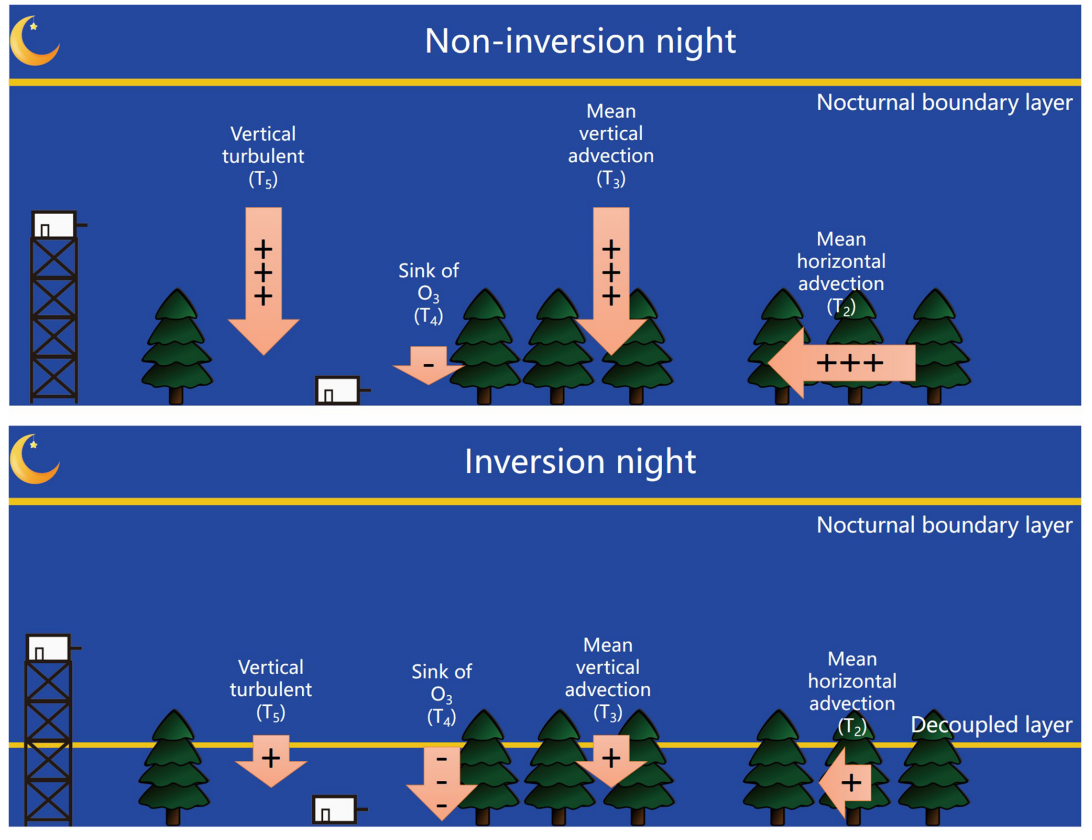

Figure 6. Schematic figure showing how vertical mixing, vertical advection, and horizontal advection influence ground-level $\mathrm{O}_{3}$ concentrations differently on non-inversion nights and inversion nights at the SMEAR II station.

no longer balanced by a large flux of $\mathrm{O}_{3}$ from upper layers. However, the stabilization of ground-level $\mathrm{O}_{3}$ concentrations at nonzero values after the initial fast decrease suggests that a small amount of inflow, either via $N_{3}$ or $N_{5}$, is still taking place.

Therefore, the differences between the ground and tower measurements were due to the joint effects of (i) decoupling between the stably stratified near-ground layer and the canopy top and the consequent formation of a shallow layer, (ii) weakening of advective and turbulent flux transport terms thereby inhibiting mass exchange between the ground decoupled layer and the remaining nocturnal boundary layer, and (iii) an increased surface area-to-volume ratio within the decoupled layer thereby enhancing $N_{4}$.

Examination of the selected HOMs was useful and efficient to assess the changes in HOMs; however, such an analysis might only indicate the major formation pathways. Hence, it was also worthwhile to have a holistic view of the entire mass spectra and all the detected HOMs. The mass defect (MD) plot (Fig. 7) separates all identified compounds according to their exact masses on the $x$ axis and the deviation from the integer mass on the $y$ axis. Each circle represents a compound, with the areas scaled by concentrations and colored by the ratios between tower and ground concentrations. Figure $7 \mathrm{a}$ and $\mathrm{b}$ are MD plots showing the mean spectra of the selected non-inversion night (11 September) and inversion night (8 September), respectively. Without the formation of a decoupled layer, nearly the same concentration distributions of HOMs were observed. In contrast, during the inversion night ( 8 September, Fig. $7 b$ ), large differences could be found between the two measurement heights. Moreover, a significant fraction of the ground HOMs disappeared on the inversion night, and the concentrations of the remaining HOMs were also lower, confirming the aforementioned results obtained with the selected HOM groups.

\subsection{Study limitations}

Several limitations still exist in this study. From the measurement side, one major concern was the comparability between our two CI-APi-TOF mass spectrometers. In the worst case, our conclusion might be biased if instrument responses changed due to some parameter that correlated with the observed inversions. The main parameters in this case would be ambient temperature and RH. As both instruments were located in temperature-controlled containers and the sample flow was mixed $1: 2$ with dry sheath air in the CI-APi-TOF drift tube, neither of these were expected to yield such large changes. However, for confirmation, we compared the detailed spectral evolution during days and nights of the study. Figure 8 shows an example of hourly changes of the ratios between tower and ground HOMs, over a $24 \mathrm{~h}$ period without nighttime temperature inversion (11 September). During this period, ambient temperatures changed from $19.1^{\circ} \mathrm{C}(12: 00)$ to $8.8^{\circ} \mathrm{C}(07: 00)$ at ground level, and from 17.9 to $8.1^{\circ} \mathrm{C}$ at tower level. Ambient RHs also increased from $72 \%$ to $96 \%$ at ground level, and from $74 \%$ to $98 \%$ at tower level. While some scatter is visible in the $200-300 \mathrm{Th}$ range during some parts of the night, good agreement was observed between the 

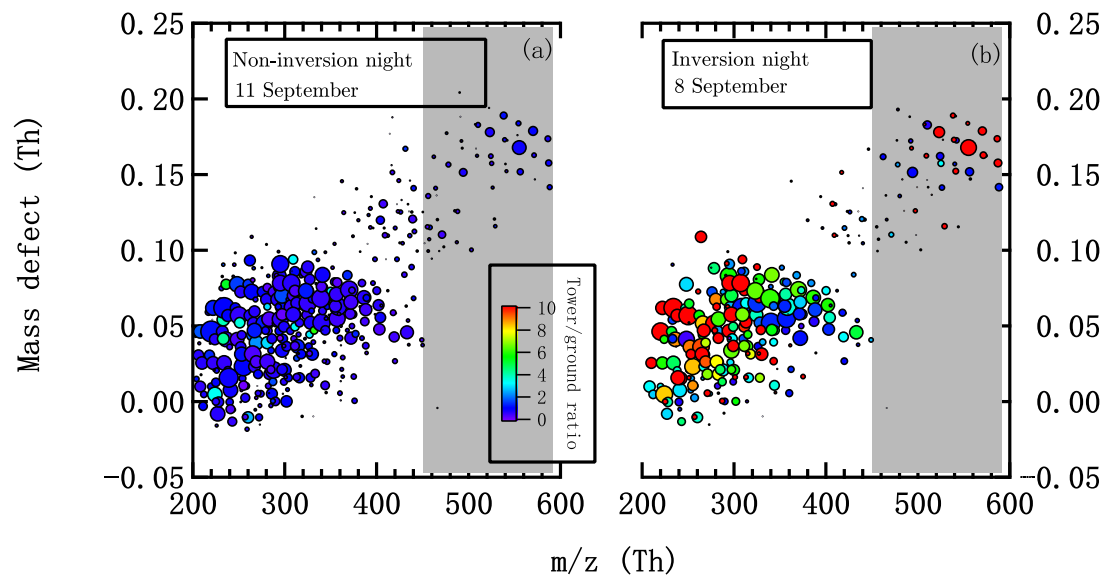

Figure 7. Mass defect (MD) plots of the selected (a) non-inversion night case (11 September) and (b) inversion night case (8 September). Color code indicates the ratios between tower and ground HOM concentrations. The grey shaded area denotes the dimer range $(m / z 450$ $600 \mathrm{Th})$.
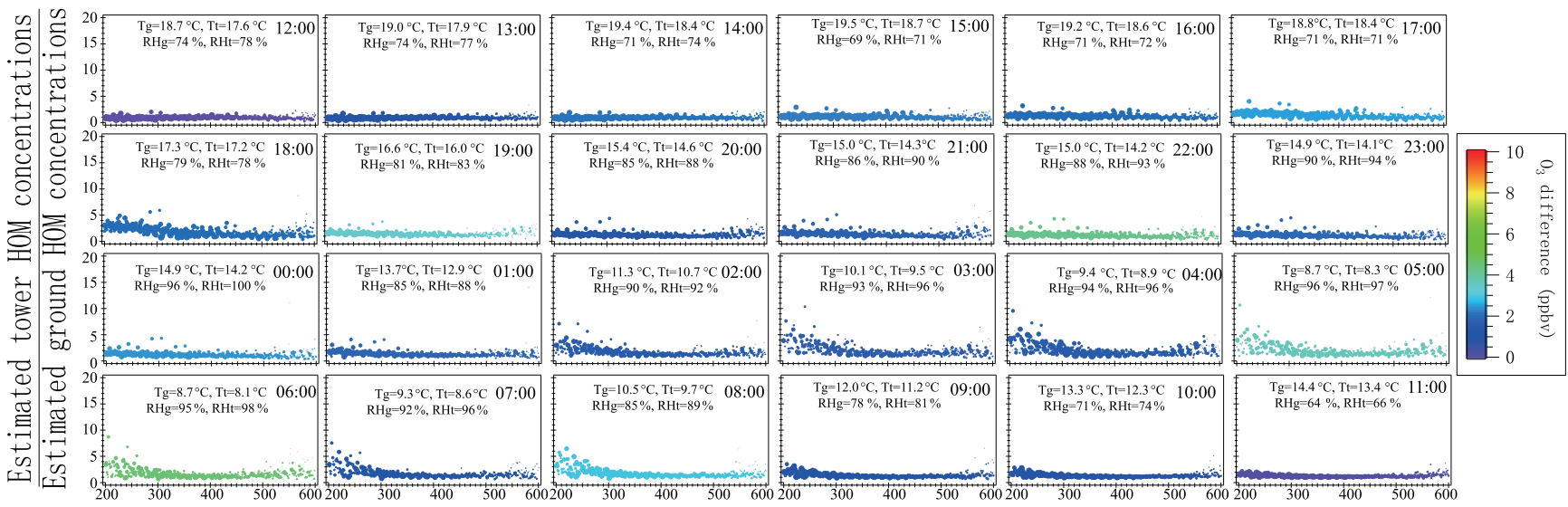

Figure 8. Hourly changes of the ratios between estimated tower and ground HOM concentrations from 12:00 on 11 September to 11:00 on 12 September (non-inversion night). Markers are sized by ground HOM concentrations and colored by the $\mathrm{O}_{3}$ difference between the tower and ground $\left(\mathrm{O}_{3_{\text {tower }}}-\mathrm{O}_{3_{\text {ground }}}\right)$. Hourly ambient temperatures at ground $(\mathrm{Tg})$ and tower $(\mathrm{Tt})$ levels and $\mathrm{RH}$ at ground $(\mathrm{RHg})$ and tower $(\mathrm{RHt})$ levels are shown in each subplot.

two instruments throughout the night, despite large variability in temperatures and RHs.

In contrast, during a $24 \mathrm{~h}$ period with nighttime temperature inversion (8 September, shown in Fig. 9), the ratios agreed well only during daytime (from 12:00 to 17:00, and 09:00 to 11:00 on the next day). Between these two periods, temperature and RH were most of the time in the same range as on 11 September (when no strong deviations were observed), but now the HOM behavior changed dramatically between the two heights. The ratios increased from $\sim 1$ (during daytime) up to $\sim 20$ at 07:00 for some of the measured molecules.

Figures 8 and 9 clearly imply that the large differences between ground and tower HOM concentrations were driven by temperature inversions and consequent changes in the composition of the air in the two detached layers. Large changes in HOMs were observed only when the ground temperature was lower than the tower temperature and when the ozone concentration at ground level was several parts per billion lower than at the tower (shown as a color scale in Figs. 8 and 9). Absolute temperatures or RHs at the two heights were not able to explain the changes. As a concrete example, good agreement was observed at 07:00 on 12 September, while ambient temperatures were low (ground and tower temperatures were 9.3 and $8.6^{\circ} \mathrm{C}$, respectively) and $\mathrm{RHs}$ were high (ground and tower RHs were $92 \%$ and $96 \%$, respectively), but large deviations were found at 20:00, 8 September, when higher temperatures (ground and tower temperatures were 10.2 and $12.1{ }^{\circ} \mathrm{C}$, respectively) and lower RHs (ground and tower RHs were $88 \%$ and $76 \%$, respectively) were observed. In other words, neither low temperatures nor high RHs caused large changes to our instruments. Instead, 


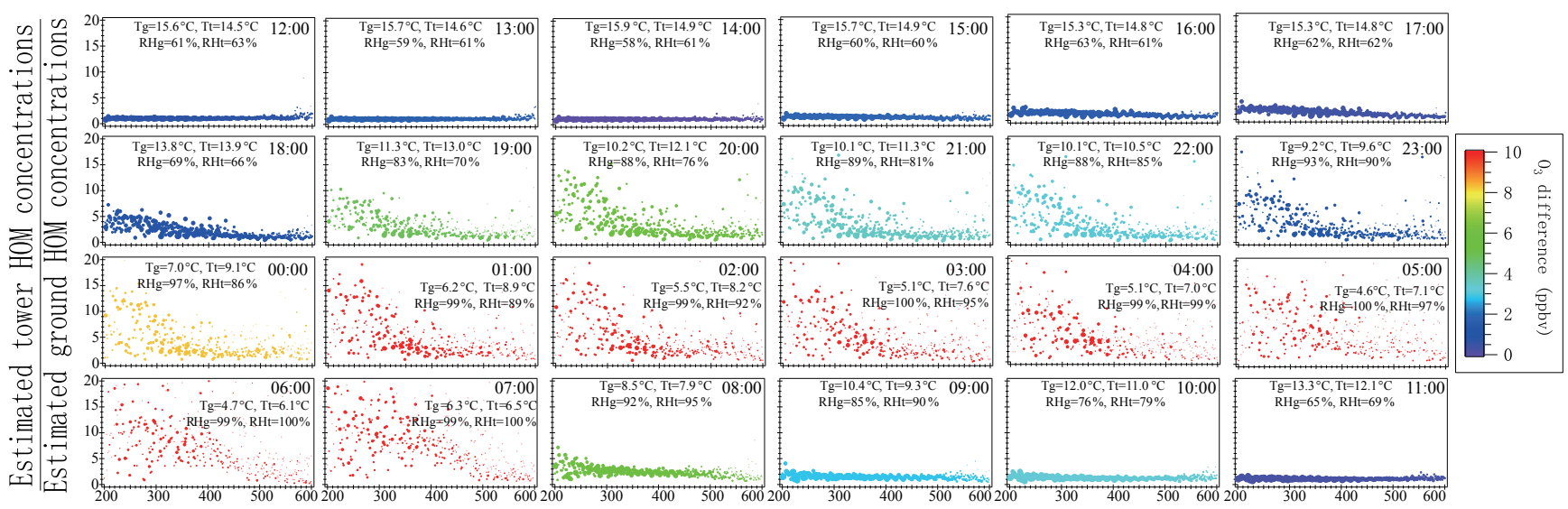

Figure 9. Hourly changes of the ratios between estimated tower and ground HOM concentrations from 12:00 on 8 September to 11:00 on 9 September (inversion night). Markers are sized by ground HOM concentrations and colored by the $\mathrm{O} 3$ difference between tower and ground $\left(\mathrm{O}_{3_{\text {tower }}}-\mathrm{O}_{3_{\text {ground }}}\right)$. Hourly ambient temperatures at ground $(\mathrm{Tg})$ and tower $(\mathrm{Tt})$ levels and $\mathrm{RH}$ at ground (RHg) and tower (RHt) levels are shown in each subplot.

the large discrepancies between the two CI-APi-TOFs were only observed when other key parameters (like ozone) were found to deviate considerably between the two heights.

From the micrometeorology side, the contribution from the potential micrometeorological processes in the layer between 1.5 and $4.2 \mathrm{~m}$ (between the sampling heights of the ground HOMs and other parameters) could not be estimated with the current experiment design (i.e., only two measurement heights). Similarly, the influence from horizontal advection could not be entirely ruled out as a reason for the reduced ground-level HOM concentrations (and other significantly changed species) because of the possible horizontal inhomogeneity of HOM precursors and oxidants below the canopy. However, our conclusion was confirmed by the incompatibility between the increasing ground-level MT and $\mathrm{CO}_{2}$ concentrations and the advection hypothesis (i.e., all species would show similar tendencies if advection played a major role), indicating the influence of horizontal and vertical advection is probably minor when compared to the increasing sink. However, conclusive evidence is still needed, which highlights the need for joint vertical-planar HOM studies, measuring both vertical and horizontal distribution of HOM concentrations.

\section{Conclusion}

Highly oxygenated molecules (HOMs) were measured above the canopy and at ground level (below the canopy) in a boreal forest environment during the IBAIRN campaign that took place in September 2016. Boundary layer dynamics and micrometeorology were found to be important factors that influence the abundance of and trends in HOMs at ground level, by perturbing both their sources and sinks. In the wellmixed boundary layer (e.g., during daytime or nights with- out strong inversion), HOM concentrations and other measured species were overall similar between the ground and tower measurements. In contrast, much lower ground-level HOM concentrations were observed when nighttime temperature inversion and formation of a decoupled layer occurred below the canopy. On the one hand, the production of the ground-level HOMs could be affected by the decreasing $\mathrm{O}_{3}$ concentrations and the increasing MT concentration in the shallow layer. On the other hand, the surface area-to-volume ratio dramatically increased in the shallow layer compared to the nocturnal boundary layer. The possibility of losses on surfaces for ground-level HOMs became much larger than usual during inversion nights. The enhanced interaction of air in the decoupled layer with the forest floor was supported by increased concentrations of $\mathrm{CO}_{2}$, emitted mainly from the ground, in this layer.

We have presented the first detailed measurements of HOMs below and above the canopy across a wide range of atmospheric stability conditions. The results highlight the significance of near-ground boundary layer dynamics and micrometeorological processes on the ambient HOMs, showing that ground-based HOM measurement at this site might not be representative for the entire nocturnal boundary layer. Conventionally, field measurements of HOMs and other parameters are mostly performed close to the ground, and the possible effect of boundary layer dynamics and micrometeorological processes to the HOM concentrations has rarely been considered. Aerosol particle growth and SOA formation rates at ground level are likely to be influenced by the reduced HOM concentrations on the inversion nights. However, there are still limitations due to current experiment design, such as horizontal separation in instrument setup, or the uncertainties from using point measurements at two heights to infer larger-scale exchange. Clearly, more vertical and planar measurements of HOMs are needed to confirm the 
emerging picture presented here. Influence of boundary layer dynamics should be better characterized and evaluated in future field campaigns.

Data availability. The time series of the measured trace gases, meteorological parameters, and estimated total HOM concentrations at the ground and tower levels will be available at the end of December 2018 (https://doi.org/10.5281/zenodo.1489079, Zha, 2018). For other data please contact the first author via email (qiaozhi.zha@helsinki.fi).

Supplement. The supplement related to this article is available online at: https://doi.org/10.5194/acp-18-17437-2018-supplement.

Author contributions. QZ, MR, and ME designed the study. QZ, CY, HJ, MR, NS, JA, and SS collected the data. QZ and CY analyzed the data. QZ wrote the paper. All coauthors contributed to data interpretation and commented on the paper.

Competing interests. The authors declare that they have no conflict of interest. Douglas R. Worsnop is affiliated with Aerodyne Research, who produce the CI-APi-TOF instruments used in this study.

Acknowledgements. This work was supported by the IBAIRN project, the Academy of Finland Center of Excellence in Atmospheric Science, European commission Actris2 and Actris PPP, the European Research Council (grant 638703-COALA), transnational access from ENVRI plus, and the SMEAR II technical team. Qiaozhi Zha thanks ATM-DP (Doctoral Program in Atmospheric Sciences) graduate programs, John Crowley and the Max Plank Institute in association with the IBAIRN proposal, and the tofTools team for providing tools for mass spectrometry analysis. Gabriel Katul acknowledges the support from the US National Science Foundation (NSF-EAR-1344703, NSF-AGS-1644382), the U.S. Department of Energy (DE-SC0011461), and the University of Helsinki for supporting a 3-month sabbatical leave at the Division of Atmospheric Sciences. Otso Peräkylä thanks the Vilho, Yrjö and Kalle Väisälä Foundation.

Edited by: Kyung-Eun Min

Reviewed by: two anonymous referees

\section{References}

Aalto, P., Hämeri, K., Becker, E., Weber, R., Salm, J., Mäkelä, J. M., Hoell, C., O'dowd, C. D., Hansson, H.-C., Väkevä, M., Koponen, I. K., Buzorius, G., and Kulmala, M.: Physical characterization of aerosol particles during nucleation events, Tellus B, 53, 344358, https://doi.org/10.3402/tellusb.v53i4.17127, 2001.

Alekseychik, P., Mammarella, I., Launiainen, S., Rannik, Ü., and Vesala, T.: Evolution of the nocturnal decoupled layer in a pine forest canopy, Agr. Forest. Meteorol., 174, 15-27, https://doi.org/10.1016/j.agrformet.2013.01.011, 2013.

Bäck, J., Aalto, J., Henriksson, M., Hakola, H., He, Q., and Boy, M.: Chemodiversity of a Scots pine stand and implications for terpene air concentrations, Biogeosciences, 9, 689-702, https://doi.org/10.5194/bg-9-689-2012, 2012.

Berndt, T., Scholz, W., Mentler, B., Fischer, L., Herrmann, H., Kulmala, M., and Hansel, A.: Accretion Product Formation from Self- and Cross-Reactions of $\mathrm{RO}_{2}$ Radicals in the Atmosphere, Angew. Chem. Int. Edit., 57, 3820-3824, https://doi.org/10.1002/anie.201710989, 2018.

Bianchi, F., Tröstl, J., Junninen, H., Frege, C., Henne, S., Hoyle, C. R., Molteni, U., Herrmann, E., Adamov, A., Bukowiecki, N., Chen, X., Duplissy, J., Gysel, M., Hutterli, M., Kangasluoma, J., Kontkanen, J., Kürten, A., Manninen, H. E., Münch, S., Peräkylä, O., Petäjä, T., Rondo, L., Williamson, C., Weingartner, E., Curtius, J., Worsnop, D. R., Kulmala, M., Dommen, J., and Baltensperger, U.: New particle formation in the free troposphere: A question of chemistry and timing, Science, 352, 110912, https://doi.org/10.1126/science.aad5456, 2016.

Bianchi, F., Garmash, O., He, X., Yan, C., Iyer, S., Rosendahl, I., Xu, Z., Rissanen, M. P., Riva, M., Taipale, R., Sarnela, N., Petäjä, T., Worsnop, D. R., Kulmala, M., Ehn, M., and Junninen, H.: The role of highly oxygenated molecules (HOMs) in determining the composition of ambient ions in the boreal forest, Atmos. Chem. Phys., 17, 13819-13831, https://doi.org/10.5194/acp-17-138192017, 2017.

Chen, X., Quéléver, L. L. J., Fung, P. L., Kesti, J., Rissanen, M. P., Bäck, J., Keronen, P., Junninen, H., Petäjä, T., Kerminen, V.M., and Kulmala, M.: Observations of ozone depletion events in a Finnish boreal forest, Atmos. Chem. Phys., 18, 49-63, https://doi.org/10.5194/acp-18-49-2018, 2018.

Crounse, J. D., Nielsen, L. B., Jørgensen, S., Kjaergaard, H. G., and Wennberg, P. O.: Autoxidation of Organic Compounds in the Atmosphere, J. Phys. Chem. Lett., 4, 3513-3520, https://doi.org/10.1021/jz4019207, 2013.

Dada, L., Paasonen, P., Nieminen, T., Buenrostro Mazon, S., Kontkanen, J., Peräkylä, O., Lehtipalo, K., Hussein, T., Petäjä, T., Kerminen, V.-M., Bäck, J., and Kulmala, M.: Long-term analysis of clear-sky new particle formation events and nonevents in Hyytiälä, Atmos. Chem. Phys., 17, 6227-6241, https://doi.org/10.5194/acp-17-6227-2017, 2017.

Eerdekens, G., Yassaa, N., Sinha, V., Aalto, P. P., Aufmhoff, H., Arnold, F., Fiedler, V., Kulmala, M., and Williams, J.: VOC measurements within a boreal forest during spring 2005: on the occurrence of elevated monoterpene concentrations during night time intense particle concentration events, Atmos. Chem. Phys., 9, 8331-8350, https://doi.org/10.5194/acp-9-8331-2009, 2009.

Ehn, M., Junninen, H., Petäjä, T., Kurtén, T., Kerminen, V.-M., Schobesberger, S., Manninen, H. E., Ortega, I. K., Vehkamäki, H., Kulmala, M., and Worsnop, D. R.: Composition and temporal behavior of ambient ions in the boreal forest, Atmos. Chem. Phys., 10, 8513-8530, https://doi.org/10.5194/acp-108513-2010, 2010.

Ehn, M., Kleist, E., Junninen, H., Petäjä, T., Lönn, G., Schobesberger, S., Dal Maso, M., Trimborn, A., Kulmala, M., Worsnop, D. R., Wahner, A., Wildt, J., and Mentel, Th. F.: Gas phase formation of extremely oxidized pinene reaction products in 
chamber and ambient air, Atmos. Chem. Phys., 12, 5113-5127, https://doi.org/10.5194/acp-12-5113-2012, 2012.

Ehn, M., Thornton, J. A., Kleist, E., Sipilä, M., Junninen, H., Pullinen, I., Springer, M., Rubach, F., Tillmann, R., Lee, B., Lopez-Hilfiker, F., Andres, S., Acir, I.-H., Rissanen, M., Jokinen, T., Schobesberger, S., Kangasluoma, J., Kontkanen, J., Nieminen, T., Kurtén, T., Nielsen, L. B., Jørgensen, S., Kjaergaard, H. G., Canagaratna, M., Maso, M. D., Berndt, T., Petäjä, T., Wahner, A., Kerminen, V.-M., Kulmala, M., Worsnop, D. R., Wildt, J., and Mentel, T. F.: A large source of lowvolatility secondary organic aerosol, Nature, 506, 476-479, https://doi.org/10.1038/nature13032, 2014.

Ehn, M., Berndt, T., Wildt, J., and Mentel, T.: Highly Oxygenated Molecules from Atmospheric Autoxidation of Hydrocarbons: A Prominent Challenge for Chemical Kinetics Studies, Int. J. Chem. Kinet., 49, 821-831, https://doi.org/10.1002/kin.21130, 2017.

Hari, P. and Kulmala, M.: Station for Measuring EcosystemAtmosphere Relations (SMEAR II), Boreal Environ. Res., 10, 315-322, 2005.

Hari, P., Nikinmaa, E., Pohja, T., Siivola, E., Bäck, J., Vesala, T., and Kulmala, M.: Station for measuring ecosystem-atmosphere relations: SMEAR, Phys. Physiol. For. Ecol., 9789400756, 471487, https://doi.org/10.1007/978-94-007-5603-8_9, 2013.

Heinritzi, M., Simon, M., Steiner, G., Wagner, A. C., Kürten, A., Hansel, A., and Curtius, J.: Characterization of the massdependent transmission efficiency of a CIMS, Atmos. Meas. Tech., 9, 1449-1460, https://doi.org/10.5194/amt-9-1449-2016, 2016.

Hyttinen, N., Kupiainen-Määttä, O., Rissanen, M. P., Muuronen, M., Ehn, M., and Kurtén, T.: Modeling the Charging of Highly Oxidized Cyclohexene Ozonolysis Products Using Nitrate-Based Chemical Ionization, J. Phys. Chem. A, 119, 6339-6345, https://doi.org/10.1021/acs.jpca.5b01818, 2015.

Jokinen, T., Sipilä, M., Junninen, H., Ehn, M., Lönn, G., Hakala, J., Petäjä, T., Mauldin III, R. L., Kulmala, M., and Worsnop, D. R.: Atmospheric sulphuric acid and neutral cluster measurements using CI-APi-TOF, Atmos. Chem. Phys., 12, 4117-4125, https://doi.org/10.5194/acp-12-4117-2012, 2012.

Jokinen, T., Sipilä, M., Richters, S., Kerminen, V.-M., Paasonen, P., Stratmann, F., Worsnop, D., Kulmala, M., Ehn, M., Herrmann, H., and Berndt, T.: Rapid Autoxidation Forms Highly Oxidized $\mathrm{RO}_{2}$ Radicals in the Atmosphere, Angew. Chem. Int. Edit., 53, 14596-14600, https://doi.org/10.1002/anie.201408566, 2014.

Jokinen, T., Kausiala, O., Garmash, O., Peräkylä, O., Junninen, H., Schobesberger, S., Yan, C., Sipilä, M., and Rissanen, M. P.: Production of highly oxidized organic compounds from ozonolysis of $\beta$-caryophyllene: laboratory and field measurements, Boreal Environ. Res., 21, 262-273, 2016.

Junninen, H., Ehn, M., Petäjä, T., Luosujärvi, L., Kotiaho, T., Kostiainen, R., Rohner, U., Gonin, M., Fuhrer, K., Kulmala, M., and Worsnop, D. R.: A high-resolution mass spectrometer to measure atmospheric ion composition, Atmos. Meas. Tech., 3, 10391053, https://doi.org/10.5194/amt-3-1039-2010, 2010.

Katul, G. G., Finnigan, J. J., Poggi, D., Leuning, R., and Belcher, S. E.: The Influence of Hilly Terrain on Canopy-Atmosphere Carbon Dioxide Exchange, Bound.-Lay. Meteorol., 118, 189-216, https://doi.org/10.1007/s10546-005-6436-2, 2006.
Katul, G. G., Porporato, A., Shah, S., and Bou-Zeid, E. Two phenomenological constants explain similarity laws in stably stratified turbulence, Phys. Rev. E, 89, 023007, https://doi.org/10.1103/PhysRevE.89.023007, 2014.

Kirkby, J., Duplissy, J., Sengupta, K., Frege, C., Gordon, H., Williamson, C., Heinritzi, M., Simon, M., Yan, C., Almeida, J., Tröstl, J., Nieminen, T., Ortega, I. K., Wagner, R., Adamov, A., Amorim, A., Bernhammer, A.-K., Bianchi, F., Breitenlechner, M., Brilke, S., Chen, X., Craven, J., Dias, A., Ehrhart, S., Flagan, R. C., Franchin, A., Fuchs, C., Guida, R., Hakala, J., Hoyle, C. R., Jokinen, T., Junninen, H., Kangasluoma, J., Kim, J., Krapf, M., Kürten, A., Laaksonen, A., Lehtipalo, K., Makhmutov, V., Mathot, S., Molteni, U., Onnela, A., Peräkylä, O., Piel, F., Petäjä, T., Praplan, A. P., Pringle, K., Rap, A., Richards, N. A. D., Riipinen, I., Rissanen, M. P., Rondo, L., Sarnela, N., Schobesberger, S., Scott, C. E., Seinfeld, J. H., Sipilä, M., Steiner, G., Stozhkov, Y., Stratmann, F., Tomé, A., Virtanen, A., Vogel, A. L., Wagner, A. C., Wagner, P. E., Weingartner, E., Wimmer, D., Winkler, P. M., Ye, P., Zhang, X., Hansel, A., Dommen, J., Donahue, N. M., Worsnop, D. R., Baltensperger, U., Kulmala, M., Carslaw, K. S., and Curtius, J.: Ion-induced nucleation of pure biogenic particles, Nature, 533, 521-526, https://doi.org/10.1038/nature17953, 2016.

Kulmala, L., Launiainen, S., Pumpanen, J., Lankreijer, H., Lindroth, A., Hari, P., and Vesala, T.: $\mathrm{H}_{2} \mathrm{O}$ and $\mathrm{CO}_{2}$ fluxes at the floor of a boreal pine forest, Tellus B, 60B, 167-178, https://doi.org/10.1111/j.1600-0889.2007.00327.x, 2008.

Kulmala, M., Dal Maso, M., Mäkelä, J. M., Pirjola, L., Väkevä, M., Aalto, P., Miikkulainen, P., Hämeri, K., and O'Dowd, C. D.: On the formation, growth and composition of nucleation mode particles, Tellus B, 53, 479-490, https://doi.org/10.3402/tellusb.v53i4.16622, 2001.

Kulmala, M., Kontkanen, J., Junninen, H., Lehtipalo, K., Manninen, H. E., Nieminen, T., Petäjä, T., Sipilä, M., Schobesberger, S., Rantala, P., Franchin, A., Jokinen, T., Järvinen, E., Äijälä, M., Kangasluoma, J., Hakala, J., Aalto, P. P., Paasonen, P., Mikkilä, J., Vanhanen, J., Aalto, J., Hakola, H., Makkonen, U., Ruuskanen, T., Mauldin, R. L., Duplissy, J., Vehkamäki, H., Bäck, J., Kortelainen, A., Riipinen, I., Kurtén, T., Johnston, M. V, Smith, J. N., Ehn, M., Mentel, T. F., Lehtinen, K. E. J., Laaksonen, A., Kerminen, V.-M., and Worsnop, D. R.: Direct observations of atmospheric aerosol nucleation., Science, 339, 943-946, https://doi.org/10.1126/science.1227385, 2013.

Kürten, A., Bergen, A., Heinritzi, M., Leiminger, M., Lorenz, V., Piel, F., Simon, M., Sitals, R., Wagner, A. C., and Curtius, J.: Observation of new particle formation and measurement of sulfuric acid, ammonia, amines and highly oxidized organic molecules at a rural site in central Germany, Atmos. Chem. Phys., 16, 1279312813, https://doi.org/10.5194/acp-16-12793-2016, 2016.

Launiainen, S., Katul, G. G., Grönholm, T., and Vesala, T.: Partitioning ozone fluxes between canopy and forest floor by measurements and a multi-layer model, Agr. Forest. Meteorol., 173, 85-99, https://doi.org/10.1016/j.agrformet.2012.12.009, 2013.

Lauros, J., Nilsson, E. D., Dal Maso, M., and Kulmala, M.: Contribution of mixing in the ABL to new particle formation based on observations, Atmos. Chem. Phys., 7, 4781-4792, https://doi.org/10.5194/acp-7-4781-2007, 2007. 
Mahrt, L.: Nocturnal Boundary-Layer Regimes, Bound.-Lay. Meteorol., 88, 255-278, https://doi.org/10.1023/A:1001171313493, 1998.

Mahrt, L., Vickers, D., Nakamura, R., Soler, M. R., Sun, J., Burns, S., and Lenschow, D. H.: Shallow Drainage Flows, Bound.-Lay. Meteorol., 101, 243-260, https://doi.org/10.1023/A:1019273314378, 2001.

Mammarella, I., Kolari, P., Rinne, J., Keronen, P., Pumpanen, J., and Vesala, T.: Determining the contribution of vertical advection to the net ecosystem exchange at Hyytiälä forest, Finland, Tellus B, 59, 900-909, https://doi.org/10.1111/j.1600-0889.2007.00306.x, 2007.

Mentel, T. F., Springer, M., Ehn, M., Kleist, E., Pullinen, I., Kurtén, T., Rissanen, M., Wahner, A., and Wildt, J.: Formation of highly oxidized multifunctional compounds: autoxidation of peroxy radicals formed in the ozonolysis of alkenes - deduced from structure-product relationships, Atmos. Chem. Phys., 15, 67456765, https://doi.org/10.5194/acp-15-6745-2015, 2015.

Molteni, U., Bianchi, F., Klein, F., El Haddad, I., Frege, C., Rossi, M. J., Dommen, J., and Baltensperger, U.: Formation of highly oxygenated organic molecules from aromatic compounds, Atmos. Chem. Phys., 18, 1909-1921, https://doi.org/10.5194/acp18-1909-2018, 2018.

Orlando, J. J. and Tyndall, G. S.: Laboratory studies of organic peroxy radical chemistry: an overview with emphasis on recent issues of atmospheric significance, Chem. Soc. Rev., 41, 6294, https://doi.org/10.1039/c2cs35166h, 2012.

Ouwersloot, H. G., Vilà-Guerau de Arellano, J., Nölscher, A. C., Krol, M. C., Ganzeveld, L. N., Breitenberger, C., Mammarella, I., Williams, J., and Lelieveld, J.: Characterization of a boreal convective boundary layer and its impact on atmospheric chemistry during HUMPPA-COPEC-2010, Atmos. Chem. Phys., 12, 9335-9353, https://doi.org/10.5194/acp-12-9335-2012, 2012.

Rannik, Ü., Mammarella, I., Keronen, P., and Vesala, T.: Vertical advection and nocturnal deposition of ozone over a boreal pine forest, Atmos. Chem. Phys., 9, 2089-2095, https://doi.org/10.5194/acp-9-2089-2009, 2009.

Rannik, Ü., Altimir, N., Mammarella, I., Bäck, J., Rinne, J., Ruuskanen, T. M., Hari, P., Vesala, T., and Kulmala, M.: Ozone deposition into a boreal forest over a decade of observations: evaluating deposition partitioning and driving variables, Atmos. Chem. Phys., 12, 12165-12182, https://doi.org/10.5194/acp-1212165-2012, 2012.

Rantala, P., Taipale, R., Kajos, M. K., Patokoski, J., Ruuskanen, T. M., Rinne, J., and Aalto, J.: Continuous flux measurements of VOCs using PTR-MS - Reliability and feasibility of disjunct-eddy-covariance, surface-layer-gradient, and surfacelayer-profile methods, Boreal Environ. Res., 19, 87-107, 2014.

Raupach, M. R. and Thom, A. S.: Turbulence in and above Plant Canopies, Annu. Rev. Fluid Mech., 13, 97-129, https://doi.org/10.1146/annurev.fl.13.010181.000525, 1981.

Rissanen, M. P., Kurtén, T., Sipilä, M., Thornton, J. A., Kangasluoma, J., Sarnela, N., Junninen, H., Jørgensen, S., Schallhart, S., Kajos, M. K., Taipale, R., Springer, M., Mentel, T. F., Ruuskanen, T., Petäjä, T., Worsnop, D. R., Kjaergaard, H. G., and Ehn, M.: The Formation of Highly Oxidized Multifunctional Products in the Ozonolysis of Cyclohexene, J. Am. Chem. Soc., 136, 15596-15606, https://doi.org/10.1021/ja507146s, 2014.
Taipale, R., Ruuskanen, T. M., Rinne, J., Kajos, M. K., Hakola, H., Pohja, T., and Kulmala, M.: Technical Note: Quantitative long-term measurements of VOC concentrations by PTR-MS - measurement, calibration, and volume mixing ratio calculation methods, Atmos. Chem. Phys., 8, 6681-6698, https://doi.org/10.5194/acp-8-6681-2008, 2008.

Tröstl, J., Chuang, W. K., Gordon, H., Heinritzi, M., Yan, C., Molteni, U., Ahlm, L., Frege, C., Bianchi, F., Wagner, R., Simon, M., Lehtipalo, K., Williamson, C., Craven, J. S., Duplissy, J., Adamov, A., Almeida, J., Bernhammer, A.-K., Breitenlechner, M., Brilke, S., Dias, A., Ehrhart, S., Flagan, R. C., Franchin, A., Fuchs, C., Guida, R., Gysel, M., Hansel, A., Hoyle, C. R., Jokinen, T., Junninen, H., Kangasluoma, J., Keskinen, H., Kim, J., Krapf, M., Kürten, A., Laaksonen, A., Lawler, M., Leiminger, M., Mathot, S., Möhler, O., Nieminen, T., Onnela, A., Petäjä, T., Piel, F. M., Miettinen, P., Rissanen, M. P., Rondo, L., Sarnela, N., Schobesberger, S., Sengupta, K., Sipilä, M., Smith, J. N., Steiner, G., Tomè, A., Virtanen, A., Wagner, A. C., Weingartner, E., Wimmer, D., Winkler, P. M., Ye, P., Carslaw, K. S., Curtius, J., Dommen, J., Kirkby, J., Kulmala, M., Riipinen, I., Worsnop, D. R., Donahue, N. M., and Baltensperger, U.: The role of low-volatility organic compounds in initial particle growth in the atmosphere, Nature, 533, 527-531, https://doi.org/10.1038/nature18271, 2016.

Vickers, D., Irvine, J., Martin, J. G., and Law, B. E.: Nocturnal subcanopy flow regimes and missing carbon dioxide, Agr. Forest. Meteorol., 152, 101-108, https://doi.org/10.1016/j.agrformet.2011.09.004, 2012.

Viggiano, A. A., Seeley, J. V., Mundis, P. L., Williamson, J. S., and Morris, R. A.: Rate Constants for the Reactions of $\mathrm{XO}_{3}-\left(\mathrm{H}_{2} \mathrm{O}\right)_{n}$ $(X=\mathrm{C}, \mathrm{HC}$, and $\mathrm{N})$ and $\mathrm{NO}_{3}-\left(\mathrm{HNO}_{3}\right)$ n with $\mathrm{H}_{2} \mathrm{SO}_{4}$ : Implications for Atmospheric Detection of $\mathrm{H}_{2} \mathrm{SO}_{4}$, J. Phys. Chem. A, 101, 8275-8278, https://doi.org/10.1021/jp971768h, 1997.

Yan, C., Nie, W., Äijälä, M., Rissanen, M. P., Canagaratna, M. R., Massoli, P., Junninen, H., Jokinen, T., Sarnela, N., Häme, S. A. K., Schobesberger, S., Canonaco, F., Yao, L., Prévôt, A. S. H., Petäjä, T., Kulmala, M., Sipilä, M., Worsnop, D. R., and Ehn, M.: Source characterization of highly oxidized multifunctional compounds in a boreal forest environment using positive matrix factorization, Atmos. Chem. Phys., 16, 12715-12731, https://doi.org/10.5194/acp-16-12715-2016, 2016.

Zha, Q.: Data for "Vertical characterization of highly oxygenated molecules (HOMs) below and above a boreal forest canopy", https://doi.org/10.5281/zenodo.1489079, 2018.

Zhao, J., Ortega, J., Chen, M., McMurry, P. H., and Smith, J. N.: Dependence of particle nucleation and growth on high-molecularweight gas-phase products during ozonolysis of $\alpha$-pinene, Atmos. Chem. Phys., 13, 7631-7644, https://doi.org/10.5194/acp13-7631-2013, 2013. 